\title{
CELL WALL POLYSACCHARIDES OF COMMON BEANS (Phaseolus vulgaris L.) ${ }^{1}$
}

\author{
Tânia M. SHIGA², Franco M. LAJOLO ${ }^{2}$, Tullia M.C.C. FILISETTI ${ }^{2, *}$
}

\begin{abstract}
SUMMARY
The soluble and insoluble cotyledon (SPF-Co and IPF-Co) and tegument (SPF-Te and IPF-Te) cell wall polymer fractions of common beans (Phaseolus vulgaris) were isolated using a chemical-enzymatic method. The sugar composition showed that SPF-Co was constituted of $38.6 \%$ arabinose, $23.4 \%$ uronic acids, $12.7 \%$ galactose, $11.2 \%$ xylose, $6.4 \%$ mannose and $6.1 \%$ glucose, probably derived from slightly branched and weakly bound polymers. The IPF-Co was fractionated with chelating agent (CDTA) and with increasing concentrations of $\mathrm{NaOH}$. The bulk of the cell wall polymers $(29.4 \%)$ were extracted with $4.0 \mathrm{M} \mathrm{NaOH}$ and this fraction contained mainly arabinose (55.0\%), uronic acid $(18.9 \%)$, glucose $(10.7 \%)$, xylose $(10.3 \%)$ and galactose $(3.4 \%)$. About $8.7 \%$ and $10.6 \%$ of the polymers were solubilised with CDTA and $0.01 \mathrm{M} \mathrm{NaOH}$ respectively and were constituted of arabinose (52.0 and 45.9\%), uronic acids (25.8 and $29.8 \%)$, xylose (9.6 and $10.2 \%)$, galactose $(6.1$ and $3.9 \%)$ and glucose $(6.5$ and $3.8 \%)$. The cell wall polymers were also constituted of small amounts $(5.6$ and $7.2 \%$ ) of cellulose (CEL) and of non-extractable cell wall polymers (NECW). About $16.8 \%$ and $17.2 \%$ of the polymers were solubilised with 0.5 and $1.0 \mathrm{M} \mathrm{NaOH}$ and contained, respectively, 92.1 and $90.7 \%$ of glucose derived from starch (IST). The neutral sugar and polymers solubilization profiles showed that weakly bound pectins are present mainly in SPF-Co (water-soluble), CDTA and 0.01-0.1M NaOH soluble fractions. Less soluble, highly cross-linked pectins were solubilised with 4.0M NaOH. This pectin is arabinose-rich, probably highly branched and has a higher molecular weight than the pectin present in SPF-Co, CDTA and 0.01-0.1M NaOH fractions.

Keywords: legume; pectin; carbohydrate; gas chromatography.
\end{abstract}

\section{RESUMO}

POLISSACARÍDEOS DE PAREDE CELULAR DE FEIJÕES (Phasealus vulgaris L.). Foram isoladas por método enzimático-químico as frações da parede celular de feijão (Phaseolus vulgaris L.) contendo polimeros solúveis e insolúveis obtidos do cotilédone (SPF-Co e IPFCo) e tegumento (SPF-Te e IPF-Te). A análise da composição de açúcares mostrou que a SPF-Co era composta por 38,6\% de arabinose, $23,4 \%$ de ácidos urônicos, $12,7 \%$ de galactose, $11,2 \%$ de xilose, $6,4 \%$ de manose e $6,1 \%$ de glicose, provavelmente, provenientes de polímeros fracamente ligados e contendo baixo grau de ramificação. A IPF-Co foi fracionada com agente quelante (CDTA) e com concentrações crescentes de $\mathrm{NaOH}$. A maior parte dos polímeros da parede celular (29\%) foram extraídos com $\mathrm{NaOH} 4,0 \mathrm{M}$ e continham, principalmente, arabinose (55,0\%), ácido urônico (18,9\%), glicose $(10,7 \%)$, xilose $(10,3 \%)$ e galactose $(3,4 \%)$. Cerca de $8,7 \%$ e $10,6 \%$ de polimeros foram solubilizados com CDTA e NaOH 0,01M apresentando em sua composição, arabinose (52,0 e 45,9\%), ácidos urônicos $(25,8$ e $29,8 \%)$, xilose $(9,6$ e $10,2 \%)$, galactose $(6,1$ e 3,9\%) e glicose $(6,5$ e $3,8 \%)$ respectivamente. Os polimeros da parede celular também eram constituídos por pequenas quantidades $(5,6$ e $7,2 \%)$ de celulose (CEL) e polissacarideos não-extraíveis (NECW). Cerca de $16,8 \%$ e $17,2 \%$ dos polimeros foram solubilizados com $\mathrm{NaOH} 0,5$ e 1,0M e estes continham, respectivamente, 92,1 e $90,7 \%$ de glicose proveniente de amido (IST). O perfil de solubilização dos polímeros e de açúcares neutros mostrou que as pectinas fracamente ligadas estão presentes principalmente nas frações SPF-Co (solúvel em água), CDTA e NaOH 0,01-0,1M. Pectinas menos solúveis e contendo grande quantidade de ligações cruzadas foram solubilizadas com $\mathrm{NaOH} 4,0 \mathrm{M}$. Estas pectinas ricas em arabinose, provavelmente, são altamente ramificadas e apresentam maior peso molecular do que as pectinas presentes nas frações SPF-Co, CDTA e NaOH 0,01-0,1M.

Palavras-chave: leguminosa; pectina; carboidrato, cromatografia de gás.

\section{1- INTRODUCTION}

Common bean (Phaseolus vulgaris L.) is a member of the Leguminosae, family Phaseoleae, subfamily Papilionoideae, and originated as a crop in the New World and spread to all the continents. Bean seeds serve as an important source of food energy and nutrients, especially for the populations of developing countries [6, 31].

The cell wall of different leguminous plants revealed a pectin rich structure, primarily containing arabinose [4, $11,15,19,20,22,25,33,37]$. In leguminous plants the bulk of the cell wall polysaccharides is only extracted with high hydroxide concentrations [19, 20], showing a strong association between the polymers. REICHERT [30],

\footnotetext{
1. Recebido para publicação em 11/05/2001. Aceito para publicação em 10/09/2002 (000642).

2 Departamento de Alimentos e Nutrição Experimental, Faculdade de Ciências Farmacêuticas, Universidade de São Paulo; Av. Prof. Lineu Prestes 580, CEP 05508-900, São Paulo SP Brazil [fax 5511 815-4410]; telephone 5511 3091-3624;e-mail: tullia@usp.br.

* A quem a correspondência deve ser enviada.
}

working with the cotyledon cell wall of peas, observed that it was composed to a large extent of pectic substances and hemicellulose, while its tegument consisted primarily of cellulose.

Numerous reviews have depicted plant cell walls as dynamic structures, composed of complex polysaccharides (cellulose, hemicellulose and pectins), small amounts of phenolic compounds (lignins and hydroxycinnamic acids esterified to the wall polysaccharides) and proteins (extensin and enzymes), with ionic and covalent linkages stabilizing its components $[3,9,12,32]$. Its polymeric structure dictates the textural quality of the plant based foods [7]. The de-polymerization of these polysaccharides during the cooking process leads to bean tissue softening.

Texture is one of the most important quality attributes of legume seeds, because it affects palatability and consequently consumer acceptability. Plant food texture is associated with the cell wall characteristics. Amongst these characteristics, the degree of polysaccharide solubility and the depolymerization during cooking process, is a determinant factor of texture quality. 
Many studies have associated changes in the cell wall and middle lamella polysaccharides with the development of the hard-to-cook defect, which renders legume seeds resistant to cooking $[1,18,23,34,35,40]$.

A better understanding of the cell wall polysaccharide composition and solubilization pattern could be useful to the comprehension of how these polymers are interconnected and behave during tissues heating. The polysaccharide solubilization profile is a good indication of the nature of the polymer linkages influencing food texture. Enzymatic treatments of bean tissues give us a notion of the digestion of the cell contents and of the cell wall polysaccharide behavior under enzymatic attack.

The detailed composition of the cell wall and middle lamella polysaccharides is also relevant when associating the physical and physiological properties (nutritional effects) as related to the effect of fiber in human health [26]. Moreover, a better knowledge of polymer structure help us to understand the cell wall polysaccharides disassembling mechanisms. So, the aim of this work was to suggest a new method of cell wall polymer extraction, under mild conditions, and study the polysaccharide composition and its solubilization patterns.

\section{2 - MATERIALS AND METHODS}

\section{1 - Plant Material}

Common beans (Phaseolus vulgaris L. cv. IAC - Carioca) seed, (9.9\% moisture), harvested in July, were kindly provided by the Instituto Agronômico de Campinas (Campinas, SP - Brazil).

\section{2 - Reagents}

Heat-stable $\alpha$-amylase (A-3306), protease (P-3910), amyloglucosidase (A-9913) and $\mathrm{D}(+)$ fucose standard sugar (F-2127) were purchased from Sigma Chemical Co. (St. Louis, MO). The others standard sugars, L-rhamnose (17,198-0), L-arabinose (A9, 190-6), D-xylose (X107-5), a-D-glucose (25,307-3), D-galactose $(11,2589-3)$, Dmannose $(11,258-5)$ and inositol (I-665-2) were purchased from Aldrich Chemical Co. (Milwaukee, WI). Molecular porous dialysis membrane utilized was Spectra/Por ${ }^{\circledR}$ Membrane, MWCO 12-14,000 Da from Spectrum ${ }^{\circledR}$ (Houston, TE); BCA-Protein Assay Reagent kit (Pearce $\left.{ }^{\circledR}\right)$.

\section{3 - Moisture determination}

Moisture content was taken as weight loss after heating whole bean flour at $105^{\circ} \mathrm{C}$ for $12 \mathrm{~h}$.

\section{4 - Beans cell wall isolation and fractionation}

The soluble (SPF-Co) and insoluble (IPF-Co) cotyledon and tegument (SPF-Te and IPF-Te) materials were isolated according to the chemical-enzymatic method, adapted from the procedures of PROSKY et al. [29], CARPITA [8] and MC LAUGHLING and GAY [27]. The seeds were manually de-hulled and freed from germ. The tegument and the cotyledon were ground separately in blade mills.
The flours were passed through a $0.5 \mathrm{~mm}$ sieve. About $500 \mathrm{mg}$ of cotyledon and tegument flour were incubated with $0.1 \mathrm{~mL}$ of $\alpha$-amylase in $25 \mathrm{~mL}$ of $0.08 \mathrm{M}$ sodium phosphate buffer at $\mathrm{pH} 6.0 / 30 \mathrm{~min}$ in a boiling water bath with manual stirring every $5 \mathrm{~min}$. After cooling, the $\mathrm{pH}$ was adjusted to 7.5 and treated with $0.1 \mathrm{~mL}$ of protease $(5 \mathrm{mg} / \mathrm{mL})$ at $60^{\circ} \mathrm{C}$ and with $0.3 \mathrm{~mL}$ of amyloglucosidase at $\mathrm{pH} 4.3$ with stirring (100 r.p.m.) for a period of $1 \mathrm{~h}$ for each enzyme added (Figure 1).

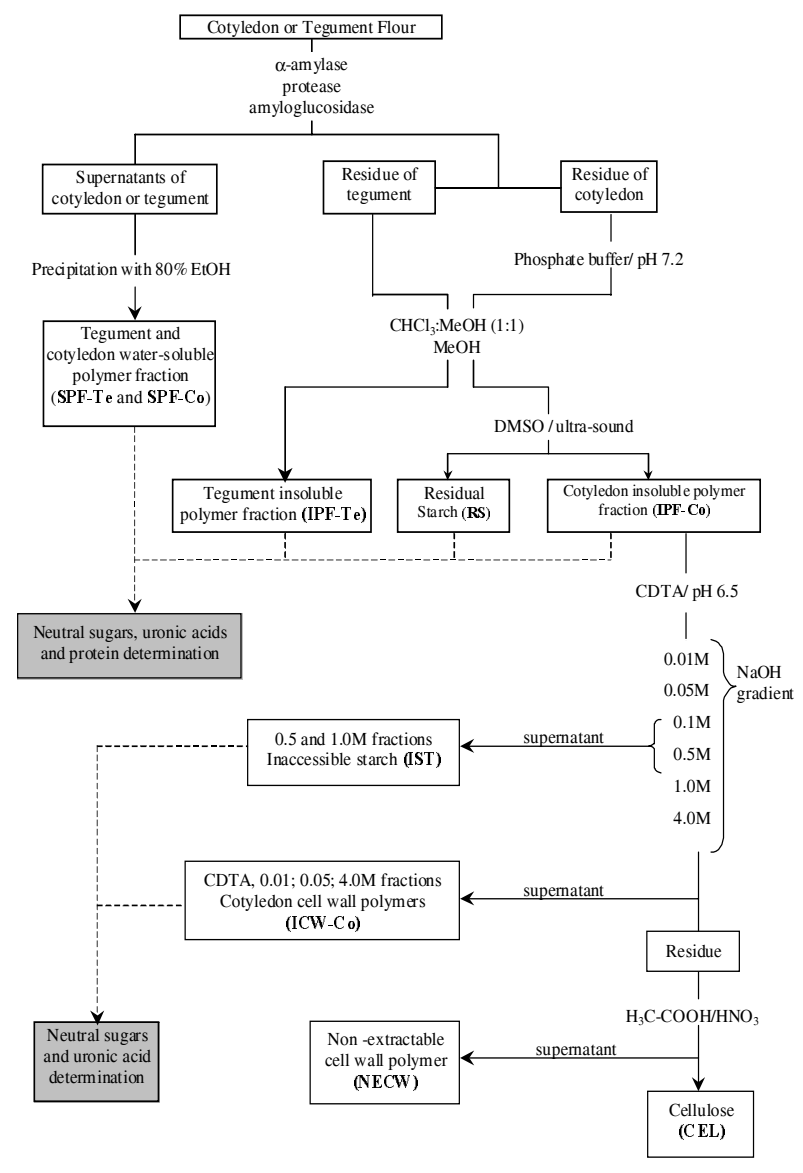

FIGURE 1. General flow chart of isolation, fractionation and analysis of the cell wall polymers of common beans (Phaseolus vulgaris L.)

The suspensions were cooled and centrifuged at $8000 \mathrm{~g} / 10 \mathrm{~min}$ and the residues washed $(3 \mathrm{x})$ with $10 \mathrm{~mL}$ of distilled water. The supernatants and the washing waters obtained from the cotyledon and tegument, were passed through fiberglass filters (GF/F Whatmann) when necessary. The extract was brought to $80 \%(\mathrm{v} / \mathrm{v})$ ethanol and the mixture allowed to precipitate for $24 \mathrm{~h}$ at $-20^{\circ} \mathrm{C}$. The alcohol insoluble precipitates obtained were washed (3x) with $10 \mathrm{~mL}$ of ice-cold $80 \%$ ethanol, suspended in distilled water, freeze dried and weighed, corresponding to the tegument and cotyledon soluble polymer fractions (SPF-Te, SPF-Co) (Figure 1). The residues of the tegument and cotyledon resulting from the enzymatic treatment, were submitted to distinct chemical treatments. 


\subsection{1 - Cotyledon chemical treatment}

The residue from the enzymatic hydrolysis of the cotyledon was treated $(2 \mathrm{x})$ with $10 \mathrm{~mL}$ of $0.5 \mathrm{M}$ sodium phosphate buffer, $\mathrm{pH} 7.2$ and with $10 \mathrm{~mL}$ of chloroform: methanol $(1: 1 ; \mathrm{v}: \mathrm{v}) / 45^{\circ} \mathrm{C} / 30 \mathrm{~min}$ and with $10 \mathrm{~mL}$ of methanol $(2 \mathrm{x})$. The remaining residue was treated with $10 \mathrm{~mL}(2 \mathrm{x})$ of $90 \%$ dimethyl sulfoxide (DMSO) for $20 \mathrm{~min}$ in an ultrasonic bath, washed $(2 \mathrm{x})$ with $10 \mathrm{~mL}$ of $90 \%$ DMSO and rinsed $(5 x)$ with distilled water. The DMSO supernatants were dialyzed $48 \mathrm{~h}$ against distilled water, freeze dried and weighed, corresponding to the residual starch fraction (RS) (Figure 1). The final residues were suspended in water, freeze dried and weighed, corresponding to the insoluble polymer fractions of the cotyledon (IPF-Co). At each stage of extraction the suspensions were pelleted by centrifugation at $8000 \mathrm{~g} /$ $15 \mathrm{~min}$ and the residues washed with water (Figure 1).

\subsection{2 - Tegument chemical treatment}

The residues obtained from the enzymatic hydrolysis of the tegument were treated $(2 \mathrm{x})$ with $10 \mathrm{~mL}$ of chloroform: methanol $(1: 1 \mathrm{v}: \mathrm{v}) / 45^{\circ} \mathrm{C} / 30 \mathrm{~min}$ and with $10 \mathrm{~mL}$ of methanol $(2 \mathrm{x})$ and washed with $10 \mathrm{~mL}(3 \mathrm{x})$ distilled water. The suspensions were centrifuged at $8000 \mathrm{~g} / 20 \mathrm{~min}$ at each step of extraction. The residues obtained were suspended in distilled water, freeze dried and weighed, corresponding to the insoluble polymer fraction of the tegument (IPF-Te) (Figure 1).

\subsection{3 - Fractionation of insoluble cotyledon polymers}

The IPF-Co was fractionated (Figure 1) following the methodology described by CARPITA [8]. Thirty milligrams of IPF-Co were extracted with $10 \mathrm{~mL} / 0.05 \mathrm{M}$ trans-1, 2diaminocyclohexane-N, N, N', N', -tetraacetic acid (CDTA)/ $\mathrm{pH} 6.5 / 16 \mathrm{~h} / 22^{\circ} \mathrm{C}$ by stirring with a few drops of toluene. The suspension was centrifuged at $1500 \mathrm{~g} /$ $10 \mathrm{~min}$ and the supernatants filtered through a GF/F filter. The filtrate was dialyzed against distilled water at $22^{\circ} \mathrm{C} / 72 \mathrm{~h}$, freeze dried and weighed, resulting in the CDTA soluble fraction. The residue was sequentially treated with $10 \mathrm{~mL}$ of $0.01,0.05,0.1,0.5$ and $1.0 \mathrm{M} \mathrm{NaOH}$ containing $3 \mathrm{mg} / \mathrm{mL} \mathrm{NaBH} 4$ for $1 \mathrm{~h} / 22^{\circ} \mathrm{C}$ under an atmosphere of $\mathrm{N}_{2}$ with constant stirring and with $4.0 \mathrm{M}$ $\mathrm{NaOH} / 16 \mathrm{~h}$ under the same conditions. The $\mathrm{NaOH}$ extracts were chilled in an ice bath and neutralized with glacial acetic acid and dialyzed for $48 \mathrm{~h}$ against distilled water, then freeze dried and weighed, resulting in the $0.01,0.05,0.1,0.5,1.0$ and $4.0 \mathrm{M}$ soluble fractions.

The insoluble material (residue) remaining after IPFCo fractionation was washed, suspended in distilled water, freeze dried and weighed. Crystalline cellulose (CEL) was obtained after digestion of the non-cellulosic polymers with a mixture of water: glacial acetic acid: nitric acid $(2: 8: 1 ; \mathrm{v}: \mathrm{v}: \mathrm{v})$. About $30 \mathrm{mg}$ of residue was treated with $10 \mathrm{~mL}$ of nitric acid reagent [39] and incubated for $90 \mathrm{~min}$ in a boiling water bath. The highly cross-linked material solubilised corresponded to the non-extractable cell wall polymer (NECW).

\section{5 - Protein composition}

The protein content was determined by the bicinchoninic acid (BCA) method [36, 41], using the BCA kit (Pearce).

\section{6 - Carbohydrate composition}

The IPF-Co, IPF-Te, SPF-Co, SPF-Te, RS were characterized for protein, neutral sugars and uronic acid contents. The sugar compositions of the IPF-Co fractions were also analyzed.

\section{7 - Uronic acids determination}

Samples were suspended or dissolved in distilled water $(0.5 \mathrm{mg} / \mathrm{mL})$ and whenever necessary, homogenized in a tissue homogenizer with a Teflon ${ }^{\circledR}$ pestle. The uronic acids were determined according to FILISETTI-COZZI and CARPITA [16]. To a $400 \mu \mathrm{L}$ sample $(0.5 \mathrm{mg} / \mathrm{mL})$ in a test tube kept on ice, $40 \mu \mathrm{L}$ of a $4.0 \mathrm{M}$ sulfamic acid-potassium sulfamate $(\mathrm{pH} 1.6)$ solution were added and mixed thoroughly. Analytical grade $(96.4 \%) \mathrm{H}_{2} \mathrm{SO}_{4}$ containing $75 \mathrm{mM}$ sodium tetraborate $(2.4 \mathrm{~mL})$ was added, and the solution stirred vigorously by vortex mixing. The solution was incubated for $20 \mathrm{~min}$ in a boiling water bath. After cooling, $40 \mu \mathrm{L}$ of $0.15 \%(\mathrm{w} / \mathrm{v}) \mathrm{m}$-hydroxydiphenyl in $\mathrm{NaOH}$ $0.5 \%(\mathrm{w} / \mathrm{v})$ was added and the mixture stirred vigorously by vortex mixing. The pink color develops to completion in about 5 to $10 \mathrm{~min}$, and is stable for about $1 \mathrm{~h}$. Absorbance was read at $525 \mathrm{~nm}$ using a standard curve containing 50,100, 150 and 200nmoles of galaturonic acid.

\section{8 - Neutral sugars determination}

The neutral sugars rhamnose (Rha), fucose (Fuc), arabinose (Ara), xylose (Xyl), mannose (Man), galactose (Gal) and glucose (Glc), excluding the glucose derived from the cellulose, released by acid hydrolysis of the polysaccharides [2], were quantitatively determined by gas-liquid chromatography after reduction and acetylation [5, 10, 17]. About $1 \mathrm{mg}$ of freeze dried product was hydrolyzed in a screw-cap vial with $1 \mathrm{~mL}$ of $2 \mathrm{M}$ trifluoroacetic acid (TFA) containing $1 \mu \mathrm{mol}$ of myo-inositol (internal standard) $/ 90 \mathrm{~min} / 120^{\circ} \mathrm{C}$ in a heating block and submitted to stirring at $30 \mathrm{~min}$ intervals towards the end of incubation, then cooled and centrifuged at $800 \mathrm{~g} / 5 \mathrm{~min}$. The supernatant was poured into a dry vial and $1 \mathrm{~mL}$ of tert-butyl alcohol (TBA) added. The mixture obtained was dried under $\mathrm{N}_{2}$ flow at $45^{\circ} \mathrm{C}$. In parallel to each group of analyses, $1 \mathrm{~mL}$ of the standard mixture $(3 \mu \mathrm{moles}$ from each standard sugar per $1 \mathrm{~mL}$ of $2 \mathrm{M}$ TFA, containing $1 \mu \mathrm{mol}$ of myo-inositol) was submitted to hydrolysis. The sugars were dissolved in $0.5 \mathrm{~mL}$ of $20 \mathrm{mg} / \mathrm{mL}$ of sodium borohydrate $\left(\mathrm{NaBH}_{4}\right)$ in DMSO (w/v), $100 \mu \mathrm{L}$ of $1.0 \mathrm{M}$ $\mathrm{NH}_{4} \mathrm{OH}$ was added and the mixture incubated at 40$45^{\circ} \mathrm{C} / 90 \mathrm{~min}$. The solution was neutralized with $100 \mu \mathrm{L}$ of glacial acetic acid, and acetylated with $100 \mu \mathrm{L}$ of 1 methylmidazol and $0.5 \mathrm{~mL}$ of acetic anhydride. The mixture was incubated in a water bath at $40-45^{\circ} \mathrm{C} /$ $30 \mathrm{~min}$. About $1.5 \mathrm{~mL}$ of distilled water was added to the final product containing the alditol acetate. The aqueous 
mixture was extracted $(2 \mathrm{x})$ with $0.5 \mathrm{~mL}$ of dichloromethane $\left(\mathrm{CH}_{2} \mathrm{Cl}_{2}\right)$ with vigorous stirring and separated by centrifuging at $800 \mathrm{~g} / 5 \mathrm{~min}$. The $\mathrm{CH}_{2} \mathrm{Cl}_{2}$ extracts were washed $(2 \mathrm{x})$ with $1 \mathrm{~mL}$ of distilled water. The washed $\mathrm{CH}_{2} \mathrm{Cl}_{2}$ extracts were poured into clean flasks and dried under $\mathrm{N}_{2}$ flow at $40-45^{\circ} \mathrm{C}$. The derivatives were dissolved in ethyl acetate and $1-3 \mu \mathrm{L}$ samples injected into a gas chromatograph equipped with a flame ionization detector (FID). The alditol acetates were separated using a $30 \mathrm{~m} \times 0.25 \mathrm{~mm}$ i.d. SP-2330 fusedsilica capillary column with a $0.20 \mu \mathrm{mm}$ film thickness (Supelco, Inc., Bellefonte, $\mathrm{PA}$ ). The column temperature was programmed from 170 to $240^{\circ} \mathrm{C}$ at $10^{\circ} \mathrm{C} / \mathrm{min}$ with a 20min hold at the highest temperature. Injector and detector temperatures were set at $250^{\circ} \mathrm{C}$. Nitrogen was used as the carrier gas at a flow rate of $30 \mathrm{~mL} / \mathrm{min}$.

\section{3 - RESULTS AND DISCUSSION}

The bean seeds (Phaseolus vulgaris L., cv Carioca) were constituted of $11.2 \%$ tegument, $87.5 \%$ cotyledon and $1.3 \%$ embryo by weight.

After the enzymatic-chemical treatment, the bean cotyledon rendered $23.1 \%$ of undigested cotyledon material (CM) composed of IPF-Co, SPF-Co and RS (Table 1).

TABLE 1. The sugar and protein compositions of bean cell wall polymers.

\begin{tabular}{|c|c|c|c|c|c|c|c|c|c|c|c|c|c|c|}
\hline \multicolumn{2}{|c|}{ FRACTION } & \multirow{2}{*}{$\%$} & \multicolumn{7}{|c|}{ NEUTRAL SUGAR $(\mu \mathrm{g} / \mathrm{mg})$} & \multirow{2}{*}{ NS } & \multirow{2}{*}{\multicolumn{2}{|c|}{$\frac{\text { UA Protein }}{\mu \mathrm{g} / \mathrm{mg}}$}} & \multirow[t]{2}{*}{ Total } & \multirow{2}{*}{ NS/UA } \\
\hline & & & Rha & Fuc & Ara & Xyl & Man & Gal & Glc & & & & & \\
\hline \multirow{2}{*}{$\begin{array}{c}\mathrm{TM} \\
(77.9 \%)\end{array}$} & SPF-Te & 5.5 & 0 & 0 & 50.4 & 20.8 & 34.8 & 36.8 & 21.0 & 163.9 & 143.7 & 184.0 & 491.6 & 1.1 \\
\hline & IPF-Te & 72.4 & 8.6 & 0 & 82.2 & 143.7 & 0 & 15.8 & 22.0 & 272.3 & 167.0 & 252.8 & 692.0 & 1.6 \\
\hline \multirow{3}{*}{$\begin{array}{c}\text { CM } \\
(23.1 \%)\end{array}$} & SPF-Co & 9.0 & 7.7 & 0 & 193.6 & 56.3 & 32.2 & 63.7 & 30.5 & 383.9 & 117.2 & 213.8 & 714.9 & 3.3 \\
\hline & IPF-Co & 12.3 & 9.4 & 0 & 249.9 & 50.2 & 0 & 33.9 & 295.5 & 638.9 & 91.2 & 145.3 & 875.4 & \\
\hline & $\mathrm{RS}$ & 1.8 & 0 & 0 & 104.4 & 17.9 & 54.6 & 54.0 & 212.7 & 443.6 & 17.1 & 244.0 & 704.7 & \\
\hline \multicolumn{15}{|c|}{ Fractionation of IPF-Co } \\
\hline \multirow{7}{*}{$\begin{array}{c}\text { ICW-Co } \\
(66 \%)\end{array}$} & CDTA & 8.7 & 0 & 0 & 454.2 & 83.9 & 0 & 53.4 & 57.0 & 648.5 & 225.2 & & 873.7 & 2.9 \\
\hline & $0.01 \mathrm{M}$ & 10.6 & 5.2 & 0 & 158.9 & 35.3 & 16.7 & 13.6 & 13.2 & 242.9 & 103.2 & & 346.1 & 2.4 \\
\hline & $0.05 \mathrm{M}$ & 2.5 & & & & & & & & & & & & \\
\hline & $0.1 \mathrm{M}$ & 1.9 & & & & & & & & & & & & \\
\hline & $4.0 \mathrm{M}$ & 29.4 & 15.1 & 0 & 499.9 & 93.4 & 0 & 30.7 & 97.2 & 736.3 & 172.0 & & 908.3 & 4.3 \\
\hline & CEL & 5.6 & & & & & & & & & & & & \\
\hline & NECW & 7.2 & & & & & & & & & & & & \\
\hline \multirow{3}{*}{$\begin{array}{c}\text { IST } \\
(34 \%)\end{array}$} & $0.5 \mathrm{M}$ & 16.8 & 0 & 0 & 10.5 & 0 & 0 & 18.8 & 645.5 & 674.8 & 26.0 & & 700.8 & \\
\hline & $1.0 \mathrm{M}$ & 17.2 & 0 & 0 & 16.4 & 0 & 0 & 28.6 & 627.8 & 672.7 & 19.5 & & 692.2 & \\
\hline & Total & 100.0 & & & & & & & & & & & & \\
\hline
\end{tabular}

SPF-Te, IPF-Te, tegument soluble and insoluble polymers fraction; SPF-Co, IPF-Co, cotyledon soluble and insoluble polymer fractions; ICW-Co, cotyledon cell wall polysaccharide; $\mathrm{CM}$ and TM, cotyledon and tegument material; CDTA and 0.01-4.0M, CDTA soluble fraction and 0.01-4.0M hydroxide soluble fractions; CEL cellulose; NECW, non extractable cell wall polymers; RS, residual starch undigested by enzyme treatment and extracted by DMSO treatment;
arabinose; Xyl, xylose; Man, mannose; Gal, galactose; Glc, glucose; NS, total neutral sugars; UA, uronic acids.

The bean cotyledon cell wall polymers were constituted of about $9 \%$ of weakly bound material extracted with water (SPF-Co). The mannose content in the SPF-Co and SPF-Te originated from the polymers present in the enzyme used for cell wall extraction. In a recent study in our laboratory, NEVES [28] also extracted bean cell wall using the same enzyme kit to hydrolyze starch and protein. NEVES [28] verified that high amounts of protein and mannose-rich polymers were present in the bean cell wall material obtained. The analysis of the composition of the enzyme kit revealed that it contained a polymer that was composed mainly 
of mannose. Hence, the presence of mannose-rich polymers in the SPF was probably due to enzyme contamination. The enzyme polymers contained high amounts of mannose $(62.3 \%)$, glucose $(14.1 \%)$, uronic acid $(12.4 \%)$, galactose $(4.9 \%)$, rhamnose $(3.2 \%)$, xylose $(1.3 \%)$, arabinose $(1.1 \%)$ and fucose $(0.9 \%)$, as can be seen in NEVES [28].

The high protein content was also attributed to the presence of enzymes in the SPF. In a recent work, a good separation of enzyme contamination was achieved using anion exchange chromatography (unpublished data).

About $1.8 \%$ of the starch (RS) was not extracted by the enzymatic treatment and was solubilised with DMSO. The bulk (12.3\%) of the polymers was insoluble in hotwater and DMSO and constituted the IPF-Co fraction. About 34\% of the IPF-Co contained high amounts of inaccessible starch (IST), that remained even after DMSO washing, being extracted by 0.5-1.0M NaOH (Table 1). The starch (RS plus IST) found in the CM is extremely hard to remove, and is well established in the literature as resistant starch $\left(\mathrm{RS}^{1}\right)$ by ENGLYST, KINGMAN and CUMMINGS [13]. However, this starch has beneficial effects, contributing in the same way as ICW-Co as an insoluble dietary fiber as can be seen in the review by HARALAMPU [21].

About $66 \%$ of the IPF-Co was constituted of wall polymers, composed of CDTA and mildly alkali soluble pectic polymers, $4.0 \mathrm{M}$ soluble polymer, crystalline cellulose (CEL) and non-extractable cell wall polymers (NECW). Protein was also found in the IPF-Co fraction (Table 1).

The weakly bound CDTA (8.7\%) and mildly alkali (0.01-0.1M) soluble polymers were composed of arabinose-rich pectic material. The low sugar recovery in the $0.01 \mathrm{M}$ fraction was due to the presence of large amounts of hydroxyproline in this fraction, as can be seen in NEVES [28]. The mass of highly cross-linked pectic polymers $(29.4 \%)$ was solubilised with $4.0 \mathrm{M} \mathrm{NaOH}$. This polymer is branched (NS/AU $=4.28$ ), with a high molecular weight and its structure is entangled with cellulose and hemicellulose microfibrils. The beans cotyledon cell wall was also composed of small amounts (5.6 and $7.2 \%$ ) of crystalline cellulose (CEL) and nonextractable cell wall polymers (NECW) (Table 1).

The sugar analysis of the 4.0M NaOH soluble polymer fractions showed that they were composed of arabinoserich polysaccharides (55.0\%) containing uronic acids (18.9\%), glucose (10.7\%) and xylose (10.3\%) (Table 2).

Probably the high levels of glucose found in the 0.5 and $1.0 \mathrm{M}$ fractions were derived from starch, because xylose was not found in these fractions (Table 2). The high amounts of glucose and the absence of xylose confirm that both fractions were mainly composed of inaccessible starch (IST). These fractions also contained small amounts of wall polymer (about 9\%) composed of uronic acids (3-4\%), arabinose (1.5-2.4\%) and galactose (3-4\%), probably derived from pectins.

The CDTA and 0.01M NaOH solubilised materials were mainly composed of arabinose (52.0 and 45.9\%), uronic acids (25.8 and 29.8\%) and xylose (9.6-10.2\%) (Table 2). The cell wall polymers extracted from each fraction showed little difference in sugar composition between them, but the differences in extractability were perceptible when the amounts of material extracted by the different solvents were observed (Tables 1 and 2). The difference in extractability probably resulted from the quantity and quality of the cross-links stabilizing the wall components. The SPF-Co pectic polysaccharides contained less arabinose than the 4.0M fraction polymers (Tables 2 and 3) and were probably less branched and bound.

TABLE 2. Sugar composition of the cotyledon insoluble cell wall polymer (IPF-Co) fractions.

\begin{tabular}{|c|c|c|c|c|c|c|c|c|c|c|c|}
\hline \multirow{2}{*}{ FRACTIONS } & \multirow{2}{*}{$\%$} & \multicolumn{7}{|c|}{ NEUTRAL SUGARS (\%) } & \multicolumn{3}{|c|}{ SUGARS (\%) } \\
\hline & & Rha & Fuc & Ara & Xyl & Man & Gal & Glc & NS & $\mathbf{U A}$ & Total \\
\hline CDTA & 8.7 & 0 & 0 & 52.0 & 9.6 & 0 & 6.1 & 6.5 & 74.2 & 25.8 & 100 \\
\hline $0.01 \mathrm{M}$ & 10.6 & 1.5 & 0 & 45.9 & 10.2 & 4.8 & 3.9 & 3.8 & 70.2 & 29.8 & 100 \\
\hline $0.5 \mathrm{M}$ & 16.8 & 0 & 0 & 1.5 & 0 & 0 & 2.7 & 92.1 & 96.3 & 3.7 & 100 \\
\hline $1.0 \mathrm{M}$ & 17.2 & 0 & 0 & 2.4 & 0 & 0 & 4.1 & 90.7 & 97.2 & 2.8 & 100 \\
\hline $4.0 \mathrm{M}$ & 29.4 & 1.7 & 0 & 55.0 & 10.3 & 0 & 3.4 & 10.7 & 81.1 & 18.9 & 100 \\
\hline CEL & 5.6 & & & & & & & & & & \\
\hline NECW & 7.2 & & & & & & & & & & \\
\hline
\end{tabular}

CDTA and 0.01-4.0M, CDTA soluble polymer and 0.01-4.0M hydroxide soluble polymers. Rha, rhamnose; Fuc, fucose; Ara, arabinose; Xyl, xylose; Man, mannose; Gal, galactose; Glc, glucose; NS, total neutral sugars; UA, uronic acids; CEL, cellulose, $\mathrm{NECW}$, non extractable cell wall polymers. The shaded area shows the fractions
containing large amounts of inaccessible starch (IST).

TABLE 3. Sugar composition of soluble and insoluble polymer fractions from the tegument (SPF-Te and IPF-Te), cotyledon (SPF-Co and IPF-Co) and residual starch (RS).

\begin{tabular}{|c|c|c|c|c|c|c|c|c|c|c|c|}
\hline \multirow{2}{*}{ RACTIONS } & \multirow{2}{*}{$\%$} & \multicolumn{7}{|c|}{ NEUTRAL SUGARS (\%) } & \multicolumn{3}{|c|}{ SUGARS (\%) } \\
\hline & & Rha & Fuc & Ara & Xyl & Man & Gal & Glc & NS & U.A. & Total \\
\hline SPF-Te & 5.5 & 0 & 0 & 16.4 & 6.8 & 11.3 & 12.0 & 6.8 & 53.3 & 46.7 & 100 \\
\hline IPF-Te & 72.4 & 2.0 & 0 & 18.7 & 32.7 & 0 & 3.6 & 5.0 & 62.0 & 38.0 & 100 \\
\hline SPF-Co & 9.0 & 1.5 & 0 & 38.6 & 11.2 & 6.4 & 12.7 & 6.1 & 76.6 & 23.4 & 100 \\
\hline IPF-Co & 12.3 & 1.3 & 0 & 34.2 & 6.9 & 0 & 4.6 & 40.5 & 87.5 & 12.5 & 100 \\
\hline RS & 1.8 & 0 & 0 & 22.7 & 3.9 & 11.8 & 11.7 & 46.2 & 96.3 & 3.7 & 100 \\
\hline
\end{tabular}

SPF-Te and IPF-Te, soluble and insoluble polymer fractions of tegument; SPF-Co and IPF-Co, soluble and insoluble polymer fractions of cotyledon; Rha, rhamnose Fuc, fucose; Ara, arabinose; Xyl, xylose; Man, mannose; Gal, galactose; Glc, glucose

The monosaccharide composition found, suggests that the bean ICW-Co was basically composed of arabinose-rich pectic polysaccharides (Table 1), probably derived from arabinan or arabinogalactans and medium amounts of hemicellulose (xyloglucan). These results are very coherent with the legume seed sugar compositions reported in the literature [11, 15, 19, 20, 25, 27, 33, 37]. BHATTY [4] inferred that the lentil cell wall was probably composed of arabinan and arabinogalactan polysaccharides, because such polysaccharides are commonly distributed in the primary cell wall of cotyledonous plants. The common beans showed a composition similar to that of Vigna radiata $[19,20]$ containing polysaccharides less readily extractable by 
CDTA and slightly alkaline solutions, the majority of the polysaccharide being solubilised by $4.0 \mathrm{M}$ base.

In a work carried out with beans (Phaseolus vulgaris L. cv Pérola), the starch was not totally eliminated by the enzymatic treatment (heat-stable $\alpha$-amylase and amyloglucosidase) and by extensive washing with DMSO (unpublished data). DMSO was shown to be a bad solvent when an accurate cell wall composition is required. The material extracted by this solvent (RS) was rich in glucose (46.2\%), but also contained arabinose (22.7\%), mannose $(11.8 \%)$, galactose $(11.7 \%)$, xylose $(3.9 \%)$ and uronic acids $(3.7 \%)$, derived from the cell wall polysaccharides (Table 3), also containing protein in its composition (Table 1). The cell walls obtained from beans (cv Pérola) after efficient cell disruption, showed low levels of 0.5 and $1.0 \mathrm{M}$ $\mathrm{NaOH}$ solubilised polymers; 6.1 and $3.4 \%$ respectively (unpublished data), instead of the 16.8 and $17.2 \%$ previously obtained (Table 2). NEVES [28] also found high amounts of glucose derived from inaccessible starch in the 0.5-1.0M NaOH soluble fractions.

Hence, 0.5 and $1.0 \mathrm{M}$ alkali extracted mainly starch instead of hemicellulose and we concluded that bean cell wall xyloglucan cannot be separated by solubilisation in these alkali concentrations. Also, hemicellulose was extracted together with arabinose-rich pectins and was found in all cell wall polymer fractions obtained, as can be seen by the xylose and glucose content (Table 2). This shows that almost all cell wall polymers are composed of arabinose-rich pectic polysaccharides extracted by hotwater, CDTA and strong alkali solutions and are difficult to separate from hemicellulose.

DMSO washing is inefficient in removing inaccessible starch (IST) without an efficient cell rupture, especially for legume seeds because the starch seems to be protected against enzymatic and chemical attack by the cell wall structure. Moreover, DMSO also extracts wall polymers. Enzymatic-chemical extraction must be carefully evaluated, according to the purpose of the analysis. To characterize cell wall components, more effective sample homogenization is necessary before the enzymatic treatment, to obtain cell wall polysaccharides, and the use of DMSO to extract starch must be reevaluated.

The tegument was composed of $77.9 \%$ of undigested tegument material (TM), $72.4 \%$ of insoluble polysaccharide fraction (IPF-Te) and 5.5\% of water-soluble polysaccharide fraction (SPF-Te) (Table 1). So, the bean cell wall furnishes large amounts of insoluble dietary fiber derived from the tegument (IPF-Te) and cotyledon (IPF-Co).

The IPF-Te polysaccharide was primarily constituted of xylose (32.7\%) with a medium level of arabinose (18.7\%) (Table 3) The high levels of xylose in IPF-Te could mean the presence of xylans and the glucose content $(5 \%)$ suggests the presence of small amounts of xyloglucans. The high quantities of uronic acids and protein (Table 1) in SPF-Te $(46.7 \%)$ and in IPF-Te $(38.0 \%)$ may be attributed, in part, to the interference of phenolic compounds in the colorimetric methods adopted. A better alternative to overcome phenolic interference in the uronic acid determination could be the use of gas chromatography $[24,38]$ or high performance liquid chromatography [14].

A careful observation of the bean cell wall composition, shows that the SPF-Te of beans was constituted of arabinose-rich polysaccharides (16.4\%), also containing galactose (12.0\%), and mannose (11.3\%), with small amounts of xylose $(6.8 \%)$ and glucose $(6.8 \%)($ Table 3). The xylose and glucose were found in a $1: 1$ proportion, and probably these sugars were derived from hemicelluloses.

\section{4 - CONCLUSIONS}

The cotyledon water-soluble polymer fraction (SPFCo) of the beans was constituted of $38.6 \%$ arabinose, $23.4 \%$ uronic acids, $12.7 \%$ galactose, $11.2 \%$ xylose, $6.4 \%$ mannose and $6.1 \%$ glucose.

The cotyledon insoluble polymer fraction (IPF-Co) was mainly constituted of polysaccharides solubilised with CDTA (8.7\%), 0.01M (10.6\%) and 4.0M NaOH (29.4\%) and by inaccessible starch (IST), solubilised with 0.5 and 1.OM NaOH. The polysaccharides solubilised with $4.0 \mathrm{M}$ $\mathrm{NaOH}$ contained mainly arabinose $(55.0 \%)$, uronic acid $(18.9 \%)$, glucose $(10.7 \%)$, xylose $(10.3 \%)$ and galactose (3.4\%). Polysaccharides solubilised with CDTA and 0.01M $\mathrm{NaOH}$ were constituted of arabinose (52.0 and 45.9\%), uronic acids (25.8 and 29.8\%), xylose (9.6 and $10.2 \%)$, galactose $(6.1$ and $3.9 \%)$ and glucose $(6.5$ and $3.8 \%)$. The polysaccharide solubilization profile showed that the bean cell wall was composed mainly of less cross-linked polysaccharides, present in the SPF-Co, CDTA and 0.01M $\mathrm{NaOH}$ fractions and by highly cross-linked pectins solubilised by $4.0 \mathrm{M} \mathrm{NaOH}$. These pectins are rich in arabinose and, to a lesser degree, in galactose. Medium amounts of hemicellulose, composed of glucose and xylose, were present too.

The 0.5M (16.8\%) and 1.0M (17.2\%) NaOH extracted material contained respectively, 92.1 and $90.7 \%$ of glucose, which was mainly constituted of inaccessible starch (IST) and negligible pectic material. The residual starch (RS) that remained after enzymatic treatment and the IST represent together an insoluble dietary fiber in the human diet. It is very hard to obtain starch free cell wall material from beans, due to the presence of resistant starch. This starch, constituted of retrograded starch protected by the cell wall structure, is not attacked by enzymes and is little extracted by DMSO.

The polysaccharide solubilization profile showed the nature of the polymer linkages. These linkages influence food texture and could contribute to an understanding of the development of the hard-to-cook defect where the nature and number of inter and intra-molecular crosslinks could contribute to alter the rheological properties and render the beans hard.

\section{5 - REFERENCES}

[1] AGUILERA, J.M.; RIVERA, R. Hard-to-cook defect in black beans: hardening rates, water imbibition and multiple 
mechanism hypothesis. Food Res. Int., v. 25, n.2, p. 101-108, 1992.

[2] ALBERShEIM, P.; NEVINS, D.J.; ENGLISH, P.D.; KARR, A. A method for analysis of sugars in plant cell wall polysaccharides by gas chromatography. Carbohydr. Res., v. 5, p. 340-345, 1967.

[3] BENNET, A.B.; ROSE, J.K.C. Cooperative disassembly of the cellulose-xyloglucan network of plant cell walls: parallels between cell expansion and fruit ripening. Trends Plant Sci., v. 4, n.5, p. 176-183, 1999.

[4] BHATTY, R.S. Cooking quality of lentils: the role of structure and composition of cell walls. J. Agric. Food Chem., v. 38, n. 2, p. 376-383, 1990.

[5] BLAKENEY, A.B.; HARRIS, P.J.; HENRY, R.J.; STONE, B.A. A simple and rapid preparation of alditol acetates for monosaccharides analysis. Carbohydr. Res., v. 113, n. 2, p. 291-299, 1983.

[6] BRESSANI, R. Grain quality of common beans. Food Rev. Int., v. 9, n. 2, p. 237-297, 1993.

[7] BRETT, C.; WALDRON, K. Physiology and biochemistry of plant cell walls, $2^{\text {nd }}$ ed.; Chapman $\&$ Hall, London, p. 173-186, p. 222-224, 1996.

[8] CARPITA, N.C. Hemicellulosic polymers of cell walls of Zea coleoptiles. Plant Physiol., v. 72, n.2, p. 515-52 1, 1983.

[9] CARPITA, N.C.; GIBEAUT, D.M. Structural models of primary cell walls in flowering plants: consistency of molecular structure with the physical properties of the walls during growth. Plant J., v. 3, n. 1, p. 1-30, 1993.

[10] CARPITA, N.C.; WHITTERN, D. A highly substituted glucuronoarabinoxylan from developing maize coleoptile. Carbohydr. Res., v.146, n.1, p.129-140, 1986.

[11] CHAMP, M.; BRILLOUET, J.M.; ROUAU, X. Non-starchy polysaccharides of Phaseolus vulgaris, Lens esculenta, and Ciccer arietinum seeds. J. Agric. Food Chem., v. 34, n.2, p. 326-329, 1986.

[12] COSGROVE, D.J. Assembly and enlargement of the primary cell wall in plants. Annu. Rev. Cell Dev. Biol, v.13, p.171-201, 1997.

[13] ENGLYST H.N.; KINGMAN S.M.; CUMMINGS J.H. Classification and measurement of nutritionally important starch fraction. Eur. J. Clin Nutr (suppl 2), v. 46, p. 33S-50S, 1992.

[14] ENGLYST, H.N.; QUIGLEY, M.E. Determination of the uronic acid constituents of non-starch polysaccharides by Highperformance liquid chromatography with pulse amperometric detection. Analyst, v. 119, n. 7, p. 15111518, 1994.

[15] EVANS, A.J.; CHEUnG, P.C.K.; CHEetham, N.W.H. The carbohydrate composition of cotyledons and hulls of cultivars of Lupinus angustifolius from Western Australia. J. Sci. Food Agri., v.61, n. 2, p.189-194, 1993.

[16] FILISETTI-COZZI; T.M.C.C.; CARPITA, N.C. Measurement of uronic acid without interference from neutral sugars. Anal. Biochem., v. 197, n.1, p. 57-162, 1991.

[17] FOX, A.; MORGAN, S.L.; GILBART, J. Preparation of alditol acetate and their analysis by gas chromatography (CG) and mass spectrometry (MS). In Biermann, C.J., McGinnis, G.D. (Ed.) Analysis of carbohydrates by GLC and MS. Boca Raton: CRC Press, 1989. p 87-117.

[18] GARCIA, E; LAJOLO, F.; SWANSON, B.G. A comparative study of normal and hard-to-cook brazilian common bean (Phaseolus vulgaris): Ultrastructural and histochemical aspects. Food Struct., v. 12, p. n.2, 147-154, 1993.

[19] GOONERATNE, J.; MAJSAK-NEWMAN, G.; ROBERTSON, J.A.; SELVENDRAN, R.R. Investigation of factors that affect the solubility of dietary fiber, as nonstarch polysaccharides, in seed tissues of mung bean (Vigna radiata) and black gram (Vigna mungo). J. Agric Food Chem., v. 42, n.3, p. 605-611, 1994 a.

[20] GOONERATNE, J.; NEEDS P.W.; RYDEN, P.; SELVENDRAN, R.R. Structural features of cell wall polysaccharides from the cotyledons of mung bean Vigna radiata. Carbohydr. Res., v. 265, n.1, p. 61-77, 1994b.

[21] HARALAMPU, S.G. Resistant starch - a review of the physical properties and biological impact of $\mathrm{RS}_{3}$. Carbohydr. Polym., v. 41, n. 1, p. 285-292, 2000.

[22] HUISMAN, M.M.H.; SCHOLS, H.A.;VORAGEN A.G.J. Enzymatic degradation of cell wall polysaccharides from soybean meal. Carbohydr. Polym., v. 38, n. 4, p. 299307, 1999.

[23] JONES, P.M.B., BOULTER, D. The cause of reduced cooking rate in Phaseolus vulgaris following adverse storage conditions. J. Food Sci., v. 48, n. 2, p. 623-649, 1983.

[24] KIM, J.B., CARPITA, N.C. Changes in esterfication of uronic acid groups of cell wall polysaccharides during elongation of maize coleoptiles. Plant. Physiol, v.98, n.2, p. 646653, 1992.

[25] LOZOVAYA, V.V.; ZABOTINA, O.A.; WIDHOLM, J.M. Synthesis and turnover of cell wall polysaccharides and starch in photosynthetic soybean suspension cultures. Plant Physiol., v. 111, n. 2, p. 921-929, 1996.

[26] MC DOUGALL, G. J.; MORRISON, I.M.; STEWART, D.; HILLMAN, J.R. Plant cell wall as dietary fibre: range, structure, processing and function. J. Sci. Food. Agric., v. 70, n.2, p. 133-150, 1996.

[27] Mc LAUGHLIN, M.A.; GAY, M.L. Differentiation of dietary fiber sources by chemical characterization. In FURDA, I., BRINE, C.J.(Ed.), New developments in dietary fiber; New York: Plenum, 1990; p. 295-310.

[28] NEVES T.R.M. Endurecimento de feijão (Phaseolus vulgaris L.): proteinas da parede celular ricas em hidroxiprolina. São Paulo, 2000. Tese de doutorado (Doutora em Ciência dos Alimentos) - Faculdade de Ciências Farmacêuticas, Universidade de São Paulo (USP).

[29] PROSKY, L.; ASP, N.G. SCHWEIZER,T.F.; DEVRIES, J.W.; FURDA, I. Determination of insoluble, soluble, and total dietary fiber in foods and food products: interlaboratory study. J. Assoc. Off. Anal. Chem., v.71, n. 5, p.10171023, 1988.

[30] REICHERT, R.D. Quantitative isolation and estimation of cell wall material from dehulled pea (Pisum sativum) flours and concentrates. Cereal Chem., v. 58, n. 4, p. 266-27, 1981.

[31] REYES-MORENO, C.; PAREDES-LÓPEZ, O. Hard-to-cook phenomenon in common beans - A review. Crit. Rev. Food Sci. Nutr., v. 33, n. 3, p. 227-286, 1993.

[32] RODIONOVA, N.A.; BEZBORODOV, A.M. Localization of enzyme systems that degrade cell wall polysaccharides in higher plants: pectinases (review). Appl. Biochem. Microbiol., v. 33, n. 5, p. 467-487, 1997.

[33] RYDEN, P.; SELVENDRAN, R. Cell-wall polysaccharides and glycoproteins of parenchymatous tissues of runner bean (Phaseolus coccineus). Biochem. J., v. 269,n. 2, p. 393402, 1990.

[34] SELVENDRAN, R.R.; O'NEILL, M. Isolation and analysis of cell walls from plant material. Methods Biochem. Anal., v.32, p. 25-153, 1987.

[35] SHOMER, I.; PASTER, N.; LINDNER, P.; VASILIVER, R. The role of cell wall structure in the hard-to-cook phenomenon in beans (Phaseolus vulgaris L.). Food Struct., v. 9, n. 2, p. 139-149, 1990. 
[36] SMITH, P.K.; KROHN R.I.; HERMANSON G.T.; MALLIA A.K., GARTNER F.H.; PROVENZANO M.D.; FUJIMOTO E.K.; GOEKE N.M.; OLSON B.J.; KLENK D.C. Measurement of protein using bicinchoninic acid. Anal. Biochem., v. 150, n. 1, p. 76-85, 1985.

[37] TALBOTT, L.D.; RAY, P.M. Molecular size and separability features of pea cell wall polysaccharides. Plant Physiol., v.98, n. 1, p.357-368, 1992.

[38] TAYLOR, R.L., CONRAD, H.E. Stoichiometric depolymerization of polyuronides and glycosaminoglycuronans to monosaccharides following reduction of their carbodiimide-activated carboxyl groups. Biochemistry, v.11, n.8, p. 1383-1388, 1972.

[39] UPDEGRAFF, D.M. Semimicro determination of cellulose in biological materials. Anal. Biochem v.32, n. 3, p. 420424, 1969.

[40] VARRIANO-MARTSON, E.; JACKSON, G.M. Hard-to-cook phenomenon in beans. Structural changes during storage and inhibition. J. Food Sci., v.46, n. 3, p.13791385, 1981.

[41]WIECHELMAN, K.J.; BRAUN, R.D.; FITZPATRICK. Investigation of the bicinchoninic acid protein assay: identification of the groups responsible for color formation. Anal. Biochem., v. 175, n.1, p. 231-237, 1988.

\section{6 - ACKNOWLEDGEMENTS}

The authors would like to acknowledge Fundação de Amparo à Pesquisa do Estado de São Paulo (FAPESP), SP-Brazil (Process no 92/00342-0) and Conselho Nacional de Desenvolvimento Científico e Tecnológico (CNPq) for the financial support and scholarship.

We thanks Dr. Nicholas C. Carpita, Department of Botany and Plant Pathology, Purdue University for his valuable advice on cell wall characterization. 